\title{
Assessing physical activity, nutrient intake and obesity in middle-aged adults in Akuse, Lower Manya Krobo, Ghana
}

\author{
David Adjatey Nyakotey, Alberta Seyram Ananga and \\ Charles Apprey \\ Department of Biochemistry and Biotechnology, KNUST, Kumasi, Ghana
}

\begin{abstract}
Purpose - The purpose of this paper is to assess physical activity and nutrient intake and their association with obesity in apparently healthy middle-aged adults in Akuse, a rural community in the Eastern region of Ghana.

Design/methodology/approach - This cross-sectional study assessed demography and anthropometry, nutrient intakes using a 3-day repeated $24 \mathrm{~h}$ dietary recall and physical activity using the global physical activity questionnaire (GPAQ). Data were entered into Microsoft excel and analyzed with SPSS version 25.

Findings - There were 118 respondents ( 55 males, $46.6 \%$ and 63 females, $53.4 \%$ ) in the study with mean age of $45.62 \pm 6.88$ years. About $90 \%$ of respondents were physically active based on WHO physical activity recommendation. Prevalence of overweight/obesity was higher among inactive participants compared to active participants and sitting/reclining hours was significantly $(p$-value $=0.042)$ associated positively with BMI after a bivariate correlation analysis, suggesting that physical activity plays a role in obesity. About one in five respondents were obese. Mean energy intake exceeded RDA for females. Sodium intake far exceeded RDA for both males and females, putting the population at potential risk of hypertension.

Practical implications - This study demonstrates the need for intensifying health education and other obesity prevention interventions to curb the rising obesity prevalence in rural communities.

Originality/value - The study revealed that overweight/ obesity in this rural community is higher than previously reported for rural Ghana.
\end{abstract}

Keywords Nutrition, Obesity, Physical activity, Ghana

Paper type Research paper

\section{Introduction}

Obesity is a common cardio-metabolic condition and its prevalence has been on a dramatic rise in the past two decades; not only in advanced countries but also in developing nations [1, 2]. Findings from the Non-Communicable Disease Collaboration analyses of over 19 million adults revealed that the prevalence of obesity globally in 1975 had doubled by 2014 [3]. The WHO also estimated that in 2016, global obesity (as defined by BMI $\geq 30 \mathrm{~kg} / \mathrm{m}^{2}$ ) prevalence stood at $13 \%(11 \%$ in men and $15 \%$ in women aged 18 years and above) [4]. In Ghana, the increasing obesity trend is evident. Findings from a systematic review [5] revealed that the more recent studies (2007 to 2016) reported higher overweight and obesity prevalence compared to earlier studies (1998-2006). According to the Ghana Demographic and Health

(C) David Adjatey Nyakotey, Alberta Seyram Ananga and Charles Apprey. Published in Journal of Health Research. Published by Emerald Publishing Limited. This article is published under the Creative Commons Attribution (CC BY 4.0) licence. Anyone may reproduce, distribute, translate and create derivative works of this article (for both commercial and non-commercial purposes), subject to full attribution to the original publication and authors. The full terms of this licence may be seen at http:// creativecommons.org/licences/by/4.0/legalcode

Funding: No funding was received for this study.

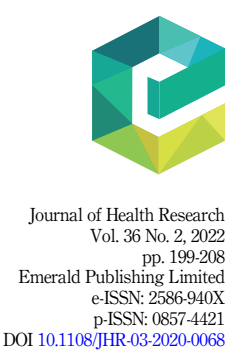

Assessing physical activity and nutrient intake 
JHR

36,2

Survey [6] findings, an estimated $15 \%$, and $3.2 \%$ of adult women and men aged 15-49, respectively, are obese. It has been shown, however, that the urban cities in Ghana have a higher prevalence of obesity than rural Ghana mainly due to the increasing westernization of diet and low physical activity levels with urban obesity prevalence standing at $34 \%$ in women and 7\% in men aged 25-70 [6]. Popkin et al. [7] stated that the obesity epidemic with its attendant non-communicable diseases are being fueled by changes in physical activity and diet patterns termed as the nutrition transition. Characterized by increased consumption of sugar-sweetened beverages, edible oils and highly processed or refined foods as well as reduced physical activity levels and increasing sedentary behavior, the nutrition transition which used to be a concern mainly in higher income countries is now widespread even in rural areas of middle and low-income countries in Asia and sub-Saharan Africa [7].

Many population and epidemiological studies have intimated that physical inactivity is one of the etiologies of obesity and its concomitant chronic conditions like atherosclerosis, diabetes and hypertension [7]. Reduced physical activity has been attributed to increasing access to advanced technologies that reduce energy expenditure at work as well as changes in transportation, leisure and entertainment activities [8, 9]. The World Health Organization thus advocates a minimum of 75 min of vigorous-intensity aerobic activity or 150 minutes of moderate-intensity aerobic activity per week for adults aged 18-64 years in order to reduce non-communicable diseases and to improve cardiorespiratory and muscular fitness [10].

Obesity is recognized as a significant risk factor for a host of chronic and other healthrelated conditions such as type 2 and gestational diabetes, hypertension, cardiovascular diseases, cancer, memory deficit and reduced cognition among adults including middle-aged adults [11-13].

In this study, we assessed the physical activity levels and nutrient intake of middle-aged adults in Akuse and their relationship with obesity, which to the best of our knowledge has not been carried out in this population.

\section{Methodology}

Study design, study site and study population

A cross-sectional design was employed in the study and the population consisted of apparently healthy middle-aged adults in Akuse. Akuse is a town in the Lower Manya Krobo District of the Eastern region of Ghana and has a population of about 3000 people, the majority of whom are employed in trading, farming and other manual labor jobs [14, 15].

\section{Sample size determination}

The minimum sample size required was determined based on the formula:

$$
n=\frac{t^{2} \times p(1-p)}{m^{2}}
$$

where: $n=$ sample size, $t^{2}=$ confidence level at $95 \%, m^{2}=$ margin of error at $5 \%$

$p=$ estimated prevalence of obesity in rural Ghana was $8.0 \%$ [5].

Hence:

$$
n=\frac{1.96^{2} \times 0.08(1-0.08)}{0.05^{2}}=113
$$


Sampling procedure

Convenience sampling was employed in choosing houses from which to draw respondents. A central point was located (the main vehicle station in Akuse). An enumerator entered the first house that faced either East, West, North or South of that central point and randomly recruited one respondent from each household. After leaving a house, the next house was entered and the house-level selection process was repeated until the required sample size was attained.

\section{Inclusion criteria}

(1) Respondents aged 35-60 years of age

(2) Apparently healthy respondents

\section{Exclusion criteria}

(1) Pregnant women

(2) Those who did not give their consent

\section{Data collection}

Information on participants' sociodemographic characteristics, physical activity levels and dietary intake was collected using structured questionnaires. Field workers/enumerators were given training prior to the commencement of data collection. Pre-testing of survey instruments was conducted to enhance field workers' understanding of the questionnaires, ensure clearness and avoid ambiguity.

\section{Anthropometry}

The following anthropometric data were measured: weight, height, visceral fat percentage, total body fat percentage, waist and hip circumference. These measurements were taken with respondents wearing light clothing. Weight was measured with an OMRON Body Composition Analyzer to the nearest $0.1 \mathrm{~kg}$. The same equipment provided values for body mass index (BMI), percentage of total body fat (BF) and visceral fat (VF). Height was measured with a stadiometer (Seca 213 mobile stadiometer, Germany) to the nearest $0.1 \mathrm{~cm}$ with respondents standing upright. Waist circumference and hip circumference measurements were taken with a non-extensible measuring tape. The waist circumference (WC) was measured just above the naval to the nearest $0.1 \mathrm{~cm}$, whereas the hip circumference $(\mathrm{HC})$ was measured at the level of the greater trochanter to the nearest $0.1 \mathrm{~cm}$. Obesity was defined as WC $>102 \mathrm{~cm}$ for males and $>88 \mathrm{~cm}$ for females, as recommended by the WHO [4].

Weight categories based on BMI were defined according to the WHO [4] criteria as follows: $<18.5 \mathrm{~kg} / \mathrm{m}^{2}$ as underweight, $18.5-24.9 \mathrm{~kg} / \mathrm{m}^{2}$ as normal weight, $25.0-29.9 \mathrm{~kg} / \mathrm{m}^{2}$ as overweight and $>30 \mathrm{~kg} / \mathrm{m}^{2}$ as obese.

\section{Dietary assessment}

The three-day repeated (two weekdays and one weekend) 24 hour dietary recall procedure was used to obtain information about the dietary intake of participants. Participants were asked to recollect all meals (food and drinks) taken as well as the time of consumption of the meal in the previous day. Common household measures were used to estimate the actual quantities of foods and drinks consumed by the participants. The nutritional composition of meals eaten was then analyzed using the Nutrient Analysis Template [16].

\section{Physical activity assessment}

The WHO's physical activity surveillance tool called the Global Physical Activity Questionnaire (GPAQ) version 2 was administered by the enumerators to assess

\author{
Assessing \\ physical \\ activity and \\ nutrient intake
}


JHR

36,2

participants' health-related physical activity levels. The questionnaire consists of 16 questions (P1-P16) that gathers information on a participant's engagement in physical activities under three main settings or domains (work-related activity, transportation to and from places and recreational activities) as well as sedentary behavior. Total physical activity per week was calculated in Metabolic Equivalents (MET- minutes) and participants who had total physical activity < 600 MET-minutes/week were categorized as being inactive while those who had total physical activity $\geq 600$ MET-minutes/ week were categorized as being active according to the WHO recommendations on physical activity for adults $[10,17]$.

\section{Data analysis}

Data were entered into Microsoft Excel and the Statistical Package for the Social Sciences (SPSS) version 23 was employed for data analysis. Sociodemographic characteristics and anthropometry were analyzed using descriptive statistics and results expressed as frequencies, percentages and means with standard deviations. Physical activity data were processed and analyzed in accordance with the Global Physical Activity Questionnaire (GPAQ) version 2 analysis framework. The Nutrient Analysis Template was employed in the analysis of dietary intake of macro- and micronutrients. Pearson's Chi-square test was performed to examine associations between categorical variables. Pearson correlation analysis was performed to determine associations between nutrient intake and anthropometric parameters. $p<0.05$ was considered to be statistically significant for analysis.

\section{Ethical approval}

This study was approved by the Committee on Human Research, Publications and Ethics of Kwame Nkrumah University of Science and Technology, School of Medical Sciences and Komfo Anokye Teaching Hospital (Ref: CHRPE/AP/408/19).

\section{Results}

\section{Sociodemographic characteristics, nutritional status and physical activity level of} respondents

This study involved a total of 118 participants out of which $63(53.4 \%)$ were female and 55 $(46.6 \%)$ were male. More than half of the participants $(56.8 \%)$ were aged 35 to 45 years. The majority of study participants $(55.9 \%)$ were married. Trading was the occupation most engaged in by the respondents $(30.5 \%)$, followed by farming $(24.6 \%)$. About $19.5 \%$ of the respondents had been educated up to tertiary level but a majority $41.5 \%$ had received secondary level education.

Concerning nutritional status, obese participants formed $19 \%$ of the study population while close to half $(46 \%)$ of the respondents were of normal weight. A total of $105(89.0 \%)$ participants met WHO physical activity recommendations of at least 600 MET-minutes per week and were thus classified as active (Table 1).

\section{Relationship between physical activity and obesity}

Following a bivariate correlation analysis, a statistically significant ( $\phi$-value $=0.042$ ) but weak positive association was observed between sitting/reclining time and BMI. Weak negative correlations were observed between physical activity (MET-min/wk) and BMI, visceral fat and waist circumference but the associations were not significant (Table 2).

Although the occurrence of overweight/ obesity $\left(\geq 25.0 \mathrm{~kg} / \mathrm{m}^{2}\right)$ was lower in active participants $(49.5 \%)$ compared to inactive participants $(69.2 \%)$, the difference was not statistically significant (Table 3). 


\begin{tabular}{|c|c|c|c|}
\hline Variable & Frequency & $\%$ & Assessing \\
\hline $\begin{array}{l}\text { Gender } \\
\text { Female } \\
\text { Male }\end{array}$ & $\begin{array}{l}63 \\
55\end{array}$ & $\begin{array}{l}53.4 \\
46.6\end{array}$ & $\begin{array}{l}\text { activity and } \\
\text { nutrient intake }\end{array}$ \\
\hline $\begin{array}{l}\text { Age (years) } \\
35-45 \\
46-55 \\
56-60 \\
\text { Mean } \pm \text { Standard deviation }\end{array}$ & $\begin{array}{c}67 \\
34 \\
17 \\
45.62 \pm 6.88\end{array}$ & $\begin{array}{l}56.8 \\
28.8 \\
14.4\end{array}$ & 203 \\
\hline $\begin{array}{l}\text { Marital status } \\
\text { Single } \\
\text { Married } \\
\text { Divorced }\end{array}$ & $\begin{array}{l}27 \\
66 \\
25\end{array}$ & $\begin{array}{l}22.9 \\
55.9 \\
21.2\end{array}$ & \\
\hline $\begin{array}{l}\text { Occupation } \\
\text { Civil servant } \\
\text { Farmer } \\
\text { Trader } \\
\text { Manual laborer }\end{array}$ & $\begin{array}{l}28 \\
29 \\
36 \\
25\end{array}$ & $\begin{array}{l}23.7 \\
24.6 \\
30.5 \\
21.2\end{array}$ & \\
\hline $\begin{array}{l}\text { Education } \\
\text { Basic } \\
\text { Secondary } \\
\text { Tertiary }\end{array}$ & $\begin{array}{l}46 \\
49 \\
23\end{array}$ & $\begin{array}{l}39.0 \\
41.5 \\
19.5\end{array}$ & \\
\hline $\begin{array}{l}\text { Nutritional status } \\
\text { Underweight } \\
\text { Normal } \\
\text { Overweight } \\
\text { Obese }\end{array}$ & $\begin{array}{r}2 \\
55 \\
39 \\
22\end{array}$ & $\begin{array}{r}1.7 \\
46.6 \\
33.1 \\
18.6\end{array}$ & \\
\hline $\begin{array}{l}\text { Waist circumference } \\
\text { (Male }>102 \mathrm{~cm} \text {; female }>88 \mathrm{~cm} \text { ) }\end{array}$ & 39 & 33.1 & \\
\hline Physical activity level & & & \\
\hline $\begin{array}{l}\text { Male } \\
\text { Active } \\
\text { Inactive } \\
\text { Female } \\
\text { Active } \\
\text { Inactive }\end{array}$ & $\begin{array}{r}51 \\
4\end{array}$ & $\begin{array}{r}92.7 \\
7.3\end{array}$ & $\begin{array}{r}\text { Table 1.; } \\
\text { Respondents' } \\
\text { characteristics, } \\
\text { nutritional status and } \\
\text { physical activity levels. }\end{array}$ \\
\hline
\end{tabular}

\begin{tabular}{|c|c|c|c|c|}
\hline & $\begin{array}{c}\text { BMI } \\
r(p \text {-value }) \\
\end{array}$ & $\begin{array}{c}\mathrm{VF} \\
r(p \text {-value }) \\
\end{array}$ & $\begin{array}{c}\text { WC } \\
r(p \text {-value })\end{array}$ & \\
\hline $\begin{array}{l}\text { PA (MET-min/wk) } \\
\text { Sitting/reclining (hours) }\end{array}$ & $\begin{array}{r}-0.12(0.101) \\
0.16\left(0.042^{*}\right)\end{array}$ & $\begin{array}{r}-0.02(0.429) \\
0.09(0.175)\end{array}$ & $\begin{array}{l}-0.038(0.341) \\
-0.10(0.143)\end{array}$ & $\begin{array}{r}\text { Table } 2 . \\
\text { Bivariate correlation } \\
\text { between physical }\end{array}$ \\
\hline $\begin{array}{l}\text { Note(s): } \mathrm{BMI}=\text { body ma } \\
\mathrm{min} / \mathrm{wk}=\text { metabolic equ }\end{array}$ & $\begin{array}{l}=\text { visceral fat, } \mathrm{W} \\
\text { tes per week. } * \mathrm{C}\end{array}$ & $\begin{array}{l}\text { rcumference, } \mathrm{P} \\
\text { significant at } \mathrm{t}\end{array}$ & $\begin{array}{l}\text { activity, MET- } \\
\text { (1-tailed) }\end{array}$ & $\begin{array}{r}\text { activity and obesity } \\
\text { parameters }\end{array}$ \\
\hline
\end{tabular}


It was observed that the mean energy intake for females exceeded the recommended dietary allowance (RDA) while that of the males was just below the RDA. The distribution of macronutrients in the total energy intake was within acceptable ranges for both males and females. While mean intake for dietary sodium far exceeded the RDA for both males and females, and that for potassium was below RDA for both genders. Intake of the antioxidants zinc and vitamin $\mathrm{C}$ met or exceeded RDA for both genders (Table 4).

\section{Relationship between nutrient intake and obesity}

Significant positive associations with BMI were observed for energy ( $\phi$-value $=0.003$ ), protein $(\phi$-value $=0.002)$, total fat $(\phi$-value $=0.002)$, carbohydrates $(\phi$-value $=0.017)$, iron $(\phi$-value $=0.002)$, sodium $(\phi$-value $=0.011)$, zinc $(\phi$-value $<0.001)$ and vitamin $\mathrm{E}$ $(\phi$-value $=0.007)$. These correlations were, however, weak. Also, waist circumference demonstrated weak significant associations with total fat intake $(\phi$-value $=0.040)$ and protein $(\phi$-value $=0.013)($ Table 5$)$.

\section{Discussion}

\section{Background characteristics of respondents}

This study involved 118 healthy middle-aged adults. Informal occupations (trading, farming and manual labor, typical "non-white collar" jobs that involve more physically engaging activities and require little or no formal education) dominated among the respondents $(76.3 \%)$. This could account for the somewhat low level of education among interviewed participants as only about one in five had been educated beyond secondary school level. Seyram [15], in his

Table 3.

Prevalence of overweight/ obesity based on physical activity levels

\begin{tabular}{lccr}
\hline Physical activity level & $<25.0 \mathrm{~kg} / \mathrm{m}^{2}$ & BMI & $\geq 25.0 \mathrm{~kg} / \mathrm{m}^{2}$ \\
\hline Active & $53(50.5)$ & $52(49.5)$ & $p$-value \\
Inactive & $\begin{array}{r}(30.8) \\
\text { Note(s): Data presented as frequency }\end{array}$ & 0.243 \\
(percentage). Fischer's exact test was performed &
\end{tabular}

\begin{tabular}{|c|c|c|c|c|}
\hline \multirow[b]{2}{*}{ Nutrient } & \multicolumn{2}{|c|}{ RDA/AI/AMDR } & \multicolumn{2}{|c|}{ Mean intake } \\
\hline & Male & Female & Male, $N=55$ & Female, $N=63$ \\
\hline Energy (kcal) & 2600 & 2000 & $2444.5 \pm 839.2^{*}$ & $2194.6 \pm 617.7^{\$}$ \\
\hline Protein (AMDR\%) & $10-35$ & $10-35$ & $12.3 \pm 2.6 \#$ & $12.7 \pm 2.8^{\#}$ \\
\hline Fat (AMDR \%) & $20-35$ & $20-35$ & $25.1 \pm 6.7 \#$ & $26.2 \pm 5.5^{\#}$ \\
\hline CHO (AMDR \%) & $45-65$ & $45-65$ & $62.5 \pm 6.5 \#$ & $61.1 \pm 6.6^{\#}$ \\
\hline Fiber $(\mathrm{g})$ & 38 & 25 & $31.6 \pm 7.2^{*}$ & $30.2 \pm 9.4^{\$}$ \\
\hline \multicolumn{5}{|l|}{ Micronutrients } \\
\hline Iron (mg) & 8 & 18 & $16.7 \pm 6.6 \$$ & $15.7 \pm 5.9^{*}$ \\
\hline Potassium (mg) & 4700 & 4700 & $3194.1 \pm 932.0^{*}$ & $3175.7 \pm 1126.0^{*}$ \\
\hline Sodium (mg) & 1500 & 1500 & $4327.5 \pm 1232.2 \$$ & $3615.0 \pm 901.0^{\$}$ \\
\hline Zinc (mg) & 11 & 8 & $11.8 \pm 5.8 \#$ & $10.4 \pm 3.9^{\$}$ \\
\hline Vitamin C (mg) & 90 & 75 & $132.6 \pm 59.1 \$$ & $117.6 \pm 57.1^{\$}$ \\
\hline Vitamin E (mg) & 15 & 15 & $9.4 \pm 5.4^{*}$ & $8.4 \pm 3.6^{*}$ \\
\hline \multicolumn{5}{|c|}{$\begin{array}{l}\text { Note(s): } \mathrm{CHO}=\text { carbohydrates, } \mathrm{AMDR}=\text { acceptable macronutrient distribution ranges. } *=\text { inadequate, } \\
\#=\text { adequate, } \$=\text { in excess. Source of RDA/ AI: Institute of Medicine. Dietary Reference Intakes for Energy, } \\
\text { Carbohydrate, Fiber, Fat, Fatty Acids, Cholesterol, Protein and Amino Acids. Washington (DC): The National } \\
\text { Academies Press; } 2002\end{array}$} \\
\hline
\end{tabular}
Mean nutrient intake of Carbohydrate, Fiber, Fat, Fatty Acids, Cholesterol, Protein and Amino Acids. Washington (DC): The National respondents 
study, recorded that rural-urban migration of youth and adults from Akuse to Accra, the commercial capital of Ghana, was common in order to access better job opportunities, higher education and the availability of improved infrastructure. This could also explain the occupation and educational distribution among respondents in the current study.

\section{Prevalence of obesity}

This study reported prevalence of 33\% and 19\% respectively for overweight and obesity, far higher than findings from the RODAM study that pegged obesity among rural Ghanaians at 4.8\% [18], the Ghana Demographic and Health Survey [6] which reported 5\% rural obesity prevalence and the systematic review by Ofori-Asenso et al. [5] reported $8.0 \%$ obesity prevalence. The prevalence of obesity has been increasing in all low- and middle- income countries and indeed globally since the 1980s [7]. It has been estimated that by 2030, over 1.2 billion adults will be obese globally [7]. This increasing obesity trend has been documented in Ghana [5, 6]. Until aggressive measures/interventions are implemented to curb it, this rising obesity trend will continue even in communities where obesity was almost non-existent or very low.

\section{Physical activity}

It has been shown that physical activity and diet (lifestyle factors) together with genetic factors interact to induce obesity and other cardiometabolic diseases [1] thus the WHO recommends at least 75 minutes of vigorous-intensity aerobic activity or 150 minutes of moderate-intensity aerobic activity every week for adults from 18 to 64 years old in order to reduce non-communicable diseases and increase cardiorespiratory and muscular fitness [10]. The population involved in this study was generally active as $89 \%$ of them met the minimum physical activity recommendation of the WHO, possibly a consequence of the vigorous activities involved in the informal sector jobs that characterized the study population.

Data on physical activity and sedentary habits in Ghana are limited, nevertheless, estimates by Abubakari et al. [19] show that among adults in West Africa, physical inactivity prevalence is about $13 \%$. This study recorded an $11 \%$ overall prevalence of physical inactivity, with female respondents being more inactive $(14.3 \%)$ compared to male respondents (7.3\%). This was in keeping with studies by Gregory et al. [20] and Abubakari et al. [19], who also found women to be more sedentary than men.

\section{Relationship between physical activity and obesity}

According to Popkin et al. [7], sedentary behaviors facilitate energy imbalance and subsequent adiposity, thus in this study, a correlation analysis showed that sitting/ reclining

\begin{tabular}{|c|c|c|c|}
\hline & $\begin{array}{c}\text { BMI } \\
r(p \text {-value })\end{array}$ & $\begin{array}{c}\mathrm{VF} \\
r(p \text {-value })\end{array}$ & $\begin{array}{c}\mathrm{WC} \\
r(p \text {-value })\end{array}$ \\
\hline Energy & $0.28(0.003)$ & $0.09(0.369)$ & $0.16(0.090)$ \\
\hline Protein & $0.28(0.002)$ & $0.10(0.306)$ & $0.23(0.013)$ \\
\hline Fat & $0.28(0.002)$ & $0.12(0.206)$ & $0.19(0.040)$ \\
\hline Carbohydrates & $0.22(0.017)$ & $0.06(0.564)$ & $0.12(0.219)$ \\
\hline Fiber & $0.04(0.695)$ & $-0.05(0.602)$ & $-0.02(0.829)$ \\
\hline Iron & $0.29(0.002)$ & $0.09(0.343)$ & $0.13(0.162)$ \\
\hline Potassium & $0.13(0.179)$ & $0.01(0.943)$ & $0.05(0.599)$ \\
\hline Sodium & $0.24(0.011)$ & $0.09(0.356)$ & $0.18(0.064)$ \\
\hline Zinc & $0.33(<0.001)$ & $0.10(0.282)$ & $0.16(0.090)$ \\
\hline Vitamin C & $0.11(0.233)$ & $-0.03(0.729)$ & $0.06(0.507)$ \\
\hline Vitamin E & $0.25(0.007)$ & $0.10(0.309)$ & $0.14(0.147)$ \\
\hline
\end{tabular}

Note(s): $\mathrm{BMI}=$ body mass index, $\mathrm{VF}=$ visceral fat, $\mathrm{WC}=$ waist circumference. Partial correlation analysis between nutrient intake and obesity parameters. Correlation was significant at $p$-value $<0.05$ (2- tailed). Controlling variables: age and gender

\section{Assessing physical activity and nutrient intake}

205

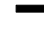


JHR

36,2 hours was significantly $(\phi=0.042)$ associated positively with BMI (Table 2$)$. It is reported in the literature that an increase in sedentary time is associated with increases in waist circumference [21] however, our study observed an inverse association between sedentary time and waist circumference. This could be attributed to the underestimation of sitting/ reclining time by study participants. Although not statistically significant, it was observed that the occurrence of overweight/ obesity (BMI $\geq 25 \mathrm{~kg} / \mathrm{m}^{2}$ ) was higher in respondents who were classified as inactive $(69.2 \%)$ compared to active respondents $(49.5 \%)$ (Table 3$)$. This suggests that physical activity may play a role in obesity in this population and is similar to other studies where it has been demonstrated that physical activity, among other things, positively modulates glucose control by increasing skeletal muscle oxidative capacity thus helping prevent positive energy balance that leads to obesity [22].

\section{Nutrient intake}

It was observed after the nutrient analysis of the 3-day repeated 24 hour dietary recall of respondents that females' mean energy intake (2194 kcal) exceeded the RDA (2000 kcal) for moderately active individuals (Table 4). Excessive energy intake is known to lead to positive energy balance and subsequent adiposity [7]. Thus, the female population in this study could be at risk of increasing body weight considering that a significant positive correlation ( $p$-value $=0.003)$ was observed between dietary energy intake and BMI. The mean contributions of the macronutrients (fats, protein and carbohydrates) to the total energy for both males and females were found to be within the AMDR. Thus, the population could be eating the right proportions of macronutrients and this prevents nutritional issues stemming from deficiency or overconsumption of certain macronutrients.

While the mean dietary intake of potassium was below RDA for both males and females, the mean dietary sodium intake far exceeded RDA. The study population could be at risk of hypertension as many studies have reported a link between high dietary sodium intake and the development of high blood pressure [23].

Anemia among women is a public health concern in Ghana and the 2014 Demographic and Health Survey report recorded an anemia prevalence of 38.9\% in the Eastern region and $42 \%$ nationally [6]. Female respondents in this study recorded the mean iron intake below RDA. Poor dietary intake of iron among women could be responsible for the high prevalence of anemia.

Evidence has shown that adequate dietary intake of antioxidant micronutrients is essential in slowing or preventing the occurrence of co-morbidities of obesity including diabetes, atherosclerosis and further CVDs resulting from systemic inflammation and oxidative stress [24]. In this study, aside from vitamin E, mean dietary intake for antioxidant micronutrients, zinc and vitamin $\mathrm{C}$ for both genders met or exceeded RDA (Table 4) and may offer protection against oxidative stress.

\section{Association between nutrient intake and obesity}

The Pearson correlation analysis showed that total energy, fat, carbohydrate and protein intake were directly associated with BMI and also fat and protein intake with waist circumference (Table 5). This suggests that higher intakes of these macronutrients lead to increased general and central obesity among middle-aged adults. Indeed, it has been shown that higher intakes of energy, fats especially saturated fat and refined carbohydrates without commensurate energy expenditure leads to weight gain and adiposity [7]. This study did not observe a significant inverse association between dietary fiber intake and BMI or waist circumference even though several studies have reported this relationship [25, 26].

\section{Limitations}

Recall bias could have been introduced during the categorization of vigorous and moderateintensity activities and their durations possibly leading to over- or- underestimation of 
physical activity engagements and also dietary intake during 24- hour dietary recall by participants.

\section{Conclusion}

The prevalence of overweight/ obesity (BMI $\geq 25 \mathrm{~kg} / \mathrm{m}^{2}$ ) among the study population was higher than previously reported for rural parts of Ghana. Considering that the vast majority of the respondents met the recommended physical activity level by WHO standards, the study population could be described as "active". However, the study population can be considered to be at risk of co-morbidities of obesity including type 2 diabetes, hypertension, dyslipidemia and subsequent cardiovascular diseases, not only because of their middle-aged status but also because of the relatively high overweight/ obesity prevalence.

It is recommended that public health education and promotion focusing on weight loss and healthy eating strategies especially for overweight or obese persons ought to be explored and intensified in the District. Also, research should be conducted to ascertain the drivers of obesity in this and other rural populations in Ghana.

\section{Conflict of Interest: None}

\section{References}

1. Malik VS, Willett WC, Hu FB. Global obesity: trends, risk factors and policy implications. Nat Rev Endocrinol. 2013 Jan; 9(1): 13-27. doi: 10.1038/nrendo.2012.199.

2. Vimaleswaran KS, Loos RJ. Progress in the genetics of common obesity and type 2 diabetes. Expert Rev Mol Med. 2010 Feb; 12: e7. doi: 10.1017/S1462399410001389.

3. NCD Risk Factor Collaboration. Trends in adult body-mass index in 200 countries from 1975 to 2014: a pooled analysis of 1698 population-based measurement studies with $19 \cdot 2$ million participants. Lancet. 2016 Apr; 387(10026): 1377-96. doi: 10.1016/s0140-6736(16)30054-x.

4. World Health Organization [WHO]. Obesity and overweight. [Cited 2019 October 5]. Available from: http:/www.who.int/mediacentre/factsheets/fs311/en/\#.

5. Ofori-Asenso R, Agyeman AA, Laar A, Boateng D. Overweight and obesity epidemic in Ghana-a systematic review and meta-analysis. BMC Public Health. 2016 Dec; 16(1): 1239. doi: 10.1186/ s12889-016-3901-4.

6. Ghana statistical service [GSS], Ghana health service [GHS], and ICF international. Ghana demographic and health survey 2014. Rockville: GSS, GHS, and ICF International; 2015.

7. Popkin BM, Adair LS, Ng SW. Global nutrition transition and the pandemic of obesity in developing countries. Nutr Rev. 2012 Jan; 70(1): 3-21. doi: 10.1111/j.1753-4887.2011.00456.x.

8. Bell AC, Ge K, Popkin BM. The road to obesity or the path to prevention: motorized transportation and obesity in China. Obes Res. 2002 Apr; 10(4): 277-83. doi: 10.1038/oby.2002.38.

9. Monda KL, Adair LS, Zhai F, Popkin BM. Longitudinal relationships between occupational and domestic physical activity patterns and body weight in China. Eur J Clin Nutr. 2008 Nov; 62(11): 1318-25. doi: 10.1038/sj.ejcn.1602849.

10. World Health Organization [WHO]. Global recommendations on physical activity for health. Geneva: WHO; 2010.

11. Cournot M, Marquié JC, Ansiau D, Martinaud C, Fonds H, Ferrières J, Ruidavets JB. Relation between body mass index and cognitive function in healthy middle-aged men and women. Neurology. 2006 Oct; 67(7): 1208-14. doi: 10.1212/01.wnl.0000238082.13860.50.

12. Gunstad J, Paul RH, Cohen RA, Tate DF, Gordon E. Obesity is associated with memory deficits in young and middle-aged adults. Eat Weight Disord. 2006 Mar; 11(1): e15-9. doi: 10.1007/bf03327747.

13. Lin WY, Pi-Sunyer FX, Liu CS, Li TC, Li CI, Huang CY, Huang KC. Betel nut chewing is strongly associated with general and central obesity in Chinese male middle-aged adults. Obesity (Silver Spring). 2009 Jun; 17(6): 1247-54. doi: 10.1038/oby.2009.38.

\section{Assessing physical activity and nutrient intake}


JHR

36,2

208

14. Lower Manya Krobo: municipal assembly. [cited 2019 October 5]. Available from: http:// lowermanya.ghanadistricts.gov.gh/?arrow $=$ dnf $\& \_=74 \& \mathrm{r}=4 \& \mathrm{rlv}=$ towns.

15. Seyram, R. Effects of rural urban migration on the care of the elderly left behind in the Akuse community. Ghana: University of Ghana; 2018.

16. University of Ghana, Food Science and Nutrition Department. The nutrient analysis template excel spreadsheet. Ghana: University of Ghana; 2010.

17. World Health Organization [WHO]. Global physical activity surveillance. [cited 2019 October 5]. Available from: http://www.who.int/chp/steps/GPAQ/en/index.html.

18. Agyemang C, Meeks K, Beune E, Owusu-Dabo E, Mockenhaupt FP, Addo J, de Graft Aikins A, Bahendeka S, Danquah I, Schulze MB, Spranger J, Burr T, Agyei-Baffour O, Amoah SK, Galbete C, Henneman P, Klipstein-Grobusch K, Nicolaou M, Adeyemo A, van Straalen J, Smeeth L, Stronks K. Obesity and type 2 diabetes in sub-Saharan Africans - is the burden in today's Africa similar to African migrants in Europe? The RODAM study. BMC Med. 2016 Oct; 14(1): 166. doi: 10.1186/s12916-016-0709-0.

19. Abubakari AR, Lauder W, Jones MC, Kirk A, Agyemang C, Bhopal RS. Prevalence and time trends in diabetes and physical inactivity among adult West African populations: the epidemic has arrived. Publ. Health. 2009 Sep; 123(9): 602-14. doi: 10.1016/j.puhe.2009.07.009.

20. Gregory CO, Dai J, Ramirez-Zea M, Stein AD. Occupation is more important than rural or urban residence in explaining the prevalence of metabolic and cardiovascular disease risk in Guatemalan adults. J Nutr. 2007; 137(5): 1314-9. doi: 10.1093/jn/137.5.1314.

21. Heinonen I, Helajarvi H, Pahkala K, Heinonen OJ, Hirvensalo M, Palve K, Tammelin T, Yang X, Juonala M, Mikkila V, Kahonen M, Lehtimaki T, Viikari J, Raitakari OT. Sedentary behaviours and obesity in adults: the cardiovascular risk in young Finns study. BMJ Open. 2013 Jun; 3(6). doi: 10.1136/bmjopen-2013-002901.

22. Gillen JB, Percival ME, Skelly LE, Martin BJ, Tan RB, Tarnopolsky MA, Gibala MJ. Three minutes of all-out intermittent exercise per week increases skeletal muscle oxidative capacity and improves cardiometabolic health. PLoS ONE. 2014; 9(11): e111489. doi: 10.1371/journal.pone.0111489.

23. Whelton PK, Carey RM, Aronow WS, Casey DE Jr, Collins KJ, Dennison Himmelfarb C, DePalma SM, Gidding S, Jamerson KA, Jones DW, MacLaughlin EJ, Muntner P, Ovbiagele B, Smith SC Jr, Spencer CC, Stafford RS, Taler SJ, Thomas RJ, Williams KA Sr, Williamson JD, Wright JT Jr 2017. ACC/AHA/AAPA/ABC/ACPM/AGS/APhA/ASH/ASPC/NMA/PCNA guideline for the prevention, detection, evaluation, and management of high blood pressure in adults: a report of the American College of cardiology/American heart association task force on clinical practice guidelines. J Am Coll Cardiol. 2018 May; 71(19): e127-e248. doi: 10.1016/j.jacc.2017.11.006.

24. Van Gaal LF, Mertens IL, De Block CE. Mechanisms linking obesity with cardiovascular disease. Nature. 2006 Dec; 444(7121): 875-80. doi: 10.1038/nature05487.

25. Liu S, Willett WC, Manson JE, Hu FB, Rosner B, Colditz G. Relation between changes in intakes of dietary fiber and grain products and changes in weight and development of obesity among middle-aged women. Am J Clin Nutr. 2003 Nov; 78(5): 920-7. doi: 10.1093/ajcn/78.5.920.

26. Howarth NC, Huang TT, Roberts SB, McCrory MA. Dietary fiber and fat are associated with excess weight in young and middle-aged US adults. J Am Diet Assoc. 2005 Sep; 105(9): 1365-72. doi: 10.1016/j.jada.2005.06.001.

\section{Corresponding author}

David Adjatey Nyakotey can be contacted at: dnyakotey@gmail.com

For instructions on how to order reprints of this article, please visit our website:

www.emeraldgrouppublishing.com/licensing/reprints.htm

Or contact us for further details: permissions@emeraldinsight.com 